\title{
Congressional Investigations and the Supreme Court
}

\author{
Robert B. McKay*
}

TN THE stress and excitement that surround the occasional dramatic 1 confrontations arising out of congressional investigations, it may be forgotten that those few imstances are atypical. For every reluctant witness who refuses to cooperate, there are hundreds who not only testify willingly, but are in fact more likely to press their testimony upon reluctant and bored committee members who simply endure the making of a record.

Between 1789 and 1963 the Supreme Court decided a scant two dozen cases that in any way challenged the authority or procedure of congressional investigating committees and fewer than half that number mvolving related issues arising out of state legislative investigations. Until 1949 no dissent was reported, and until that year no concurring opinion was filed in any case involving a legislative investigation. ${ }^{1}$ But in the more than twenty cases decided by the Court in 1949 and thereafter, the Court was divided-usually sharply so-in all except three. ${ }^{2}$ Those "modern" decisions on the power of legislative committees have stimulated considerably more comment and controversy than their small number might have suggested, yet the reason is apparent. Individual cases often developed out of public controversy that became front-page news, and beneath the surface were issues no less dramatic than conflict between Court and Congress, and sometimes as well between Congress and the executive branch.

With such ingredients potentially involved in every case, avoidance of decision is more to be expected than resolute disposition of hard problems.

* Professor of Law, New York University School of Law.

1 There were, however, earlier dissents fronl decisions against review. See, e.g., Marshall v. United States, 176 F.2d 473 (D.C. Cir. 1949), cert. denied, 339 U.S. 933 (1950) (Black, J., dissenting) ; Lawson v. United States, 176 F.2d 49 (D.C. Cir. 1949), cert. denied, 339 U.S. 934, 972 (1950) (Black, J., and Douglas, J., dissenting); Barsky v. United States, 167 F.2d 241 (D.C. Cir.), cert. denied, 334 U.S. 843 (1948), petition for rehearing denied, 339 U.S. 971 (1950) (Black, J., and Douglas, J., dissenting); United States v. Josephson, 165 F.2d 82 (2d Cir. 1947), cert. denied, 333 U.S. 838 (1948) (Douglas, J., Murphy, J., and Rutledge, J., dissenting). See also Eisler v. United States, 170 F.2d 273 (D.C. Cir.), cert. granted, 335 U.S. 857 (1948), ordered removed from docket after petitioner fled country, 338 U.S. 189 (1949).

2 Scull v. Virginia, 359 U.S. 344 (1959); Flaxer v. United States, 358 U.S. 147 (1958); United States v. Runely, 345 U.S. 41 (1953). In Rumely, however, Justices Burton and Minton did not participate, and Justices Douglas and Black, while concurring in the result, disagreed with other aspects of the decision. See also Raley v. Ohio, 360 U.S. 423 (1959), in which the Court unanimously reversed three convictions, but affirmed a fourth by a four-to-four division. In Slagle v. Ohio, 366 U.S. 759 (1961), the Court reversed two convictions, but affirmed three others by a four-to-four division. 
As a result the decided cases often provide little more than temporary solutions to particular controversies without significant carry-over of principle from one case to make predictable the solution of other cases. Until at least the late 1950's each case tended to stand alone, neither looking backward im any meaningful way for precedential support nor offering itself as a guidepost for future cases that might differ in any particular from cases already decided. The recurring pattern of judicial opimion ordinarily consisted of two parts, ritualistic repetition of the formula that reminds of inherent power and its limitations, followed by disposition of the particular case on less enduring principles. The formula is by now familiar.

The power of the Congress to conduct investigations is inherent in the legislative process. That power is broad. It encompasses inquiries concerning the administration of existing laws as well as proposed or possibly needed statutes. It includes surveys of defects in our social, economic or political system for the purpose of enabling the Congress to remedy them. It comprehends probes into departments of the Federal Government to expose corruption, inefficiency or waste. But, broad as is this power of inquiry, it is not unlimited. There is no general authority to expose the private affairs of individuals without justification in terms of the functions of the Congress. ${ }^{3}$

By repetition sufficiently frequent it may be hoped to offer a soothing mystique to quiet uncertainty about the meaning of a broad investigative power that is nonetheless quite limited.

The second ingredient of the magic incantation has often been an attempt to clothe the emperor whose nakedness had gone almost unnoticed. The trick has involved an attempt to make the empty formula seem potent. Thus, after proper appeal to the Great Platitudes, the Court has decided individual cases on the basis of such enduring trivia as whether authority to investigate "lobbying" includes the right to compel disclosure of the names of bulk purchasers of a right-wing publisher; ${ }^{4}$ whether a witness sufficiently claims the privilege against self incrimination by basing his refusal to answer on "the first and fifth amendments"; ${ }^{5}$ whether particular questions are "pertinent to the subject under inquiry" when clearly the stated pertinency requirement could have been satisfied with nothing more exacting than a reformulation of well-understood committee objectives $;^{\circ}$ and whether the indictment is drawn with sufficient particularity. ${ }^{7}$

3 Watkins v. United States, 354 U.S. 178, 187 (1957); see, e.g., Gibson v. Florida Legislative Investigation Conmi., 372 U.S. 539, 544-46 (1963); Barenblatt v. United States, 360 U.S. 109, 111-12 (1959); Sinclair v. United States, 279 U.S. 263, 291-94 (1929); Kilbourn v. Thompson, 103 U.S. 168, 190 (1881).

4 United States v. Rumely, 345 U.S. 41 (1953).

5 Qumn v. United States, 349 U.S. 155 (1955).

${ }^{6}$ Watkins v. United States, 354 U.S. 178 (1957). See also Deutch v. United States, 367 U.S. 456 (1961).

7 Russell v. United States, 369 U.S. 749 (1962). 
Not only do these dispositions fail to resolve the underlying constitutional problems; the opinions have often not even discussed the relevant questions, which are fundamental and difficult. To say that these decisions have bypassed the real issues, however, is not necessarily to criticize the Court's handling of the particular cases; and it is certainly not to say that the individual Justices do not understand perfectly well exactly what are the important, underlying issues. The reason for the unsatisfactory individual dispositions of most of the cases arises out of the very fact that all members of the Court have recognized that the most important undecided issue depends for its resolution on first amendment considerations. On this question the Court has been closely divided since the mid-1950's; in six cases the Court divided five to four, sometimes upholding, ${ }^{8}$ and sometimes rejecting, ${ }^{9}$ a contempt citation. In two other cases in which not all members of the Court took part, the divisions were four to two and five to two. ${ }^{10}$

In only a few of those cases was any attempt made to deal with the ultimate issue of whether a congressional committee can demand verbal or documentary disclosure of political beliefs and associational activities. Although Watkins v. United States was decided on the restricted ground of lack of pertimency, the majority opinion contained brave talk about the impermissibility of "exposure for the sake of exposure," prompting a narrowing concurrence from Justices Frankfurter and Harlan, and a dissent from Mr. Justice Clark. ${ }^{11}$ But the attempt there made to achieve by dictum a libertarian result at least loosely anchored to the first amendment foundered two years later in Barenblatt $v$. United States, ${ }^{12}$ and two years after that in Wilkinson v. United States ${ }^{13}$ and Braden v. United States. ${ }^{14}$ These latter three cases are the only cases in which the Court squarely ruled on the first amendment contention in the context of congressional investigations, in each instance adversely to the claim. But the Court divided five to four in each case; and there are subsequent indications that the majority may not be firm. In three later cases the Court reverted to its practice of deciding in favor of the defendant on narrow grounds. ${ }^{15}$ This may sug-

8 Braden v. United States, 365 U.S. 431 (1961); Wilkinson v. United States, 365 U.S. 399 (1961) ; Barenblatt v. United States, 360 U.S. 109 (1959); Uphaus v. Wynan, 360 U.S. 72 (1959).

${ }^{9}$ Gibson v. Florida Legislative Investigation Conın., 372 U.S. 539 (1963); Deutch v. United States, 367 U.S. 456 (1961).

10 Russell v. United States, 369 U.S. 749 (1962) (Frankfurter, J., and White, J., not participating); Hutcheson v. United States, 369 U.S. 599 (1962) (Black, J., Frankfurter, J., and White, J., not participating).

11 Watkins v. United States, 354 U.S. 178 (1957).

12360 U.S. 109 (1959); cf. Uphaus v. Wyman, 360 U.S. 72 (1959).

13365 U.S. 399 (1961).

14365 U.S. 431 (1961).

15 Gibson v. Florida Legislative Investigation Conım., 372 U.S. 539 (1963); Russell v. Umited States, 369 U.S. 749 (1962); Deutch v. United States, 367 U.S. 456 (1961). 
gest some dissatisfaction within the Court as to the Barenblatt line of decisions, particularly in view of the changes in Supreme Court membership in 1962, involving the retirement of Justices Frankfurter and Whittaker, who had voted with the majority in those cases, and their replacement by Justices Goldberg and White. Reasons are suggested below why the Barenblatt line of cases should be reconsidered. But first it may be useful to recall the earlier context out of which those cases developed.

In the late 1940's and 1950's, at the very height of the McCarthy excitement, there was widespread belief that the principal constitutional doubts about the power of congressional investigating committees had been resolved-in favor of nearly unlimited power, so long as the committees showed at least nominal deference to the principle of legislative purpose. But under the loose cover of legislative purpose could be sheltered an inquiry in aid of legislation already enacted, ${ }^{18}$ under consideration, ${ }^{17}$ or within the power of Congress to enact; ${ }^{18}$ and an inquiry bent on "informing the public" might also come within that loose concept. ${ }^{10}$ Thus, one qualified

16 There had never been any real doubt that Congress could investigate searchingly into the implementation or enforcement of congressional pohicy and the expenditure of congressional appropriations by executive departments or administrative agencies. Sinclair v. United States, 279 U.S. 263 (1929); McGrain v. Daugherty, 273 U.S. 135 (1927). Representative Jerry Voorhis put it more strongly in 1951, saying that some investigations "are authorized because Congress as a body, or at least a majority of its members, become angry at some exccutive agency, or at some organization, and decide to "take it apart." Voorhis, Inner Workings, in Congressional Investigations, $18 \mathrm{U}$. CHr. L. REv. 455, 457 (1951). However inappropriate that sort of motivation may be, there is hittle doubt that the agency in question must subinit with what grace it can. See also Landis, Constitutional Limitations on the Congressional Power of Investigation, 40 HARv. L. REv. 153, 168-94 (1926).

17 The "legislative purpose" rationale has always been understood to include, as it should, the power to search out even remotely relevant evidence bearing upon legislation proposed for congressional consideration. See, e.g., Watkins v. United States, 354 U.S. 178, 187 (1957).

18 Where Congress may go it may authorize its committees to investigate. See, e.g., Hutcheson v. United States, 369 U.S. 599, 614-17 (1962). Whether legislation is an iminediate or at most a remote goal makes no difference, a conclusion aunply supported by the fact that no challenge has ever been successful to the authority of that vigorous investigator, the House Un-American Activities Committee, despite its notably shim output of legislative proposals to Congress, and its even slimmer record of achievement in the form of legislation actually enacted.

10 When Woodrow Wilson said that the "informing function of Congress should be preferred even to its legislative function," Congressronal Governasent 303 (1917), he had in mind the publicizing of corruption or inefficiency of government agencies, and not a general power of "exposure for the sake of exposure." See Watkins v. United States, 354 U.S. 178, 200 (1957).

The doubtful extent to which the "informing function" has been carried in justification of committee inquiry is illustrated by the work of the Senate Special Committee to Investigate Organized Crime in Interstate Commerce (popularly known as the Kefauver committee). Both officially and unofficially it was acknowledged with considerable candor that a prime purpose of the investigation was to arouse the public to the dangers of organized crime. The First Interim Report stated: "The public must be made aware of the basic menace involved in gambling on a widely organized basis. ..." S. REP. No. 2370, 81st Cong., 2d Sess. 4 (1950). 
observer wrote in a 1951 symposium that "if the resolution providing for an inquiry expressly states or at least implies a legislative intent, however remote, the restrictions which remain on the congressional investigatory power seem to be almost meaningless." 20 The author of the introduction to the same symposium confidently concluded that "the central civil liberties question" at that time related to "the status of witnesses."21 By this was meant not freedom of speech and assembly protected by the first amendment, or scarcely even the privilege against self incrimination in the fifth amendment. Nor was there particularly in mind the aggravating problem of executive privilege. Rather the "status of witnesses" reference had to do with the procedural aspects of the investigative process: right to notice, opportunity to make a statement, representation by counsel, right of cross-examination, hearing in public versus executive session, televised hearings, and the like. These issues, while clearly important, were not generally regarded as having a specifically constitutional base, except in the general due process sense that might protect against real outrage. Appeal for correction was thus not addressed to the Constitution, believing that relief could not there be found. Instead, appeal was made to the congres-

The Second Interim Report was still more blunt in support of the decision to establish the committee: "It became manifest that it was also necessary to arouse the public to the threat that was imphed by permitting these dangerous and unscrupulous individuals, possessed of neither morals nor conscience, to prey upon the weakness and indifference of the average citizen." S. REP. No. 141, 82d Cong., Ist Sess. 5 (1951). And in the Final Report appeared the following:

This committee has served as a powerful searchight, exposing widespread national and local crime conditions to public gaze. Its activities have had a tremendous effect upon the whole field of law enforcement. Everywhere throughout the country citizens, made suddenly aware of the character and ramifications of organized crime, have risen up to demand greater vigilance in stamping out crime and corruption.

S. REP. No. 725, 82d Cong., 1st Sess. 1 (1951).

On the back cover of Senator Kefauver's book, Crnne IN Amrerrca (paperback ed. 1951), he is quoted as follows: "We can lick . . . organized crime ... if we recognize the alliance of criminals and their 'respectable' front men for what they are-hoodlums and despoilers rather than glamorous figures or heroes .... There is nothing that the American people cannot overcome if they know the facts."

This conmittee philosophy may well explain two significant committee decisions: the granting of permission for televised coverage of the hearings, which would not otherwise facilitate any normal legislative purpose, and the frequent holding of public hearings that duplicated almost entirely the questions and answers (or refusals to answer) already secured in executive sessions.

For a report of the somewbat similar orientation of the Senate Select Committee on Improper Activities in the Labor or Management Field (popularly known as the McClellan conimittee), see KENNEDY, THE ENEATY WITHN (1960).

$20 \mathrm{McGeary}$, Historical Development, in Congressional Investigations, 18 U. Cㅍ. L. REv. 425,438 (1951).

21 Introduction, in id. at 423 . It is not impossible that Senator McCarthy's antics could have been in mind. 
sional sense of fair play, ${ }^{22}$ a device frequently employed in recent years, but without notable impact in securing procedural reform of congressional investigations. ${ }^{23}$

The constitutional status of the legislative investigation in the early 1950's can be quickly summarized for the purpose of comparison with the somewhat different emphasis in the early 1960's. In the earlier period the power of investigation was regarded as nearly plenary so long as proper obeisance was made to the concept of a valid legislative purpose, a phrase also given broad definition. The privilege against self incrimination, although sometimes parlayed into headlines under the rubric of "pleading the fifth," was generally accepted as a basis for refusal to answer. The first amendment, however, had received surprisingly little attention as a basis for refusal to answer. ${ }^{24}$ And the executive privilege, in reliance on which government officials might refuse to answer questions or to disclose official records to Congress, had not been dealt with in any Supreme Court opinion.

By the 1960's, however, the issues had developed quite new perspectives. In United States v. Rumely ${ }^{25} \mathrm{Mr}$. Justice Frankfurter had written of "the prohibition of the First Anıendment," and in Watkins Chief Justice Warren had stated that "Clearly, an investigation is subject to the command that the Congress shall make no law abridging freedom of speech or press or assembly." ${ }^{26}$ Moreover, in Watkins the Court had concluded that "exposure for the sake of exposure" was not permissible, suggesting a somewhat undefined restriction upon the right of investigation. But in three cases a narrow majority of the Court concluded that the first amendment was not a proper basis for refusal to answer otherwise proper questions, at least in the circumstances of those cases. ${ }^{27}$ During the same period the privilege against self imcrimination had become securely grounded as a

22 See, e.g., Galloway, Proposed Reforms, in id. at 478.

23 See 1 Emerson \& Haber, Political and Crvir Rights IN THE United States 755-57 (2d ed. 1958). For a good general discussion see Maslow, Fair Procedure in Congressional Investigations: A Proposed Code, 54 Colum. L. Rev. 839 (1954). See also Newman \& Surrex, Legislation: Cases and Matersals 366-406 (1955); Rauh \& Pollitt, Right to and Nature of Representation Before Congressional Committees, 45 MrNv. L. REv. 853 (1961).

24 The issue lad been raised and decided adversely to the defendant in each of the following cases, but the Supreme Court denied review in each instance. Lawson v. United States, 176 F.2d 49 (D.C. Cir. 1949), cert. denied, 339 U.S. 934, 972 (1950); Barsky v. United States, 167 F.2d 241 (D.C. Cir.), cert. denied, 334 U.S. 843 (1948); United States v. Joseplıson, 165 F.2d 82 (2d Cir. 1947), cert. denied, 333 U.S. 838 (1948).

25345 U.S. 41, 46 (1953).

26354 U.S. at 197. See also Gibson v. Florida Legislative Investigation Comm., 372 U.S. 539 (1963); Russell v. United States, 369 U.S. 749 (1962); Hutcheson v. United States, 369 U.S. 599 (1962); Deutch v. United States, 367 U.S. 456 (1961).

27 Braden v. United States, 365 U.S. 431 (1961); Wilkinson v. United States, 365 U.S. 399 (1961) ; Barenblatt v. United States, 360 U.S. 109 (1959). 
basis for refusing to answer questions, beginning with the Quinn, Emspak, and Bart cases, ${ }^{28}$ although troublesome questions of detail remain. In one respect only was there no change in the intervening ten-year period. The Supreme Court has still not decided any case that bears upon the extent to which agency heads and lesser employees of the executive branch may refuse to answer questions and decline to produce documents relevant to an otherwise valid legislative inquiry, in reliance upon the separation-ofpowers ground of executive privilege.

\section{LEGISLATIVE PURPOSE AND THE FIRST AMENDMENT}

The modern history of judicial review of congressional investigations may be said to begin im 1953 with United States $v$. Rumely, ${ }^{29}$ in which Mr. Justice Frankfurter recognized "that there is wide concern, both in and out of Congress, over some aspects of the exercise of the congressional power of investigation." 330 This was also the first case in which the Court explicitly recognized the first amendment as a limitation on the investigatory power. In that case the House Select Committee on Lobbying Activities had demanded that Rumely, the secretary of the Committee for Constitutional Government, produce the names of persons who had made bulk purchases of right-wing books for further distribution. The majority of the Court found that an authorization to investigate "all lobbying activities intended to influence, encourage, promote, or retard legislation" went only to attempts to influence sentiment in Congress. This construction, which Justices Douglas and Black thought strained, ${ }^{31}$ was justified by the majority on the ground that "the power to inquire into all efforts of private individuals to influence public opinion . . . raises doubts of constitutionality in view of the prohibition of the First Amendinent." 32

Only Justices Douglas and Black thought the resolution was broad enough to indicate congressional approval of the inquiry in dispute, and thus only they faced the constitutional question.

If the present inquiry were sanctioned, the press would be subjected to harassment that in practical effect might be as serious as censorship. A pub-

28 Bart v. United States, 349 U.S. 219 (1955); Emspak v. United States, 349 U.S. 190 (1955) ; Quinn v. United States, 349 U.S. 155 (1955). See also Slagle v. Ohio, 366 U.S. 259 (1961); McPhaul v. United States, 364 U.S. 372 (1960); Flaxer v. United States, 358 U.S. 147 (1958).

29345 U.S. 41 (1953).

$30 \mathrm{Id}$. at 44.

31 Id. at 48 (concurring opinion).

32 Id. at 46. 
lisher, compelled to register with the Federal Government, would be subjected to vexatious imquiries. A requirement that a publisher disclose the identity of those who buy his books, pampllets, or papers is indeed the beginning of surveillance of the press. ... Since Congress could not by law require of respondent what the House demanded, it may not take the first step in an inquiry ending in fine or imprisonment. ${ }^{33}$

Rumely set the pattern for subsequent cases in a substantial majority of which the Court invalidated contempt or perjury convictions, but always on either (1) a narrow interpretation of the delegation of authority from Congress to a committee (or from a parent committee to a subcommittee); or (2) a committee failure to make sufficiently definite its purpose or the nature of the response required to its demand for information. Manifestly, these defects are all readily cured as a matter of simple congressional and committee housekeeping. Indeed, Chief Justice Warren, in Watkins, provided future committees with a blueprint of suggested procedures that would permit them to avoid these technical difficulties without in any way interfering with the scope of intended investigations or even the particularity of contemplated questions. He said:

It is the responsibility of the Congress, in the first instance, to insure that compulsory process is used only in furtherance of a legislative purpose. That requires that the instructions to an investigating committee spell out that group's jurisdiction and purpose with sufficient particularity. Those instructions are embodied in the authorizing resolution. That document is the committee's charter. ${ }^{34}$

And again:

There are several sources that can outline the "question under inquiry" in such a way that the rules against vagueness are satisfied. The authorizing resolution, the remarks of the chairman or members of the committee, or even the nature of the proceedings themselves, might sometimes make the topic clear. ${ }^{35}$

In the Watkins case itself the contempt conviction had been based on the witness' refusal to answer questions about Commumist Party membership of former associates. The Court reversed the contempt conviction because the witness had not been sufficiently apprised of the nature of the inquiry, and thus the committee had not made clear to him that the questions he refused to answer were "pertinent to the subject under inquiry." That is not, however, a holding that answers to the same questions could not have been demanded if the proper foundation had been laid. But equally Watkins should not be read to hold that the questions could have been asked. It seems clear, in the light of later decisions, that some members of 
the Court believe that, given an adequate foundation, the questions would have been proper; and other members of the Court believe that in any event the first amendment forbids such inquiry into belief and association.

In order to speculate on a proper-or at least a likely-answer to that issue, it is necessary to look back at least briefly to the early cases. Of the cases before Rumely, discussed above, there are only two in which contempt convictions were set aside on a complaint that no valid legislative purpose was being served. The more important is the inuch-discussed Kilbourn v. Thompson, ${ }^{36}$ in which the Court upheld an action for false imprisonment brought by an unwilling witness against the Sergeant at Arms of the House of Representatives who enforced a forty-five-day commitment under the authority of the House. The matter arose out of an 1876 House resolution which set up a five-member committee to look into the affairs of the bankrupt Jay Cooke \& Co., particularly in connection with a real estate pool alleged to have been part of a scheme to defraud creditors, including the United States Government. Kilbourn, the witness, refused to answer questions as to the place of residence of five members of the pool, and he was tried directly by the House itself for that alleged contempt. Although the Court did not deny that the "question was pertinent and material to the question under inquiry,"37 the confinement was held improper under a separation-of-powers argument, concluding that this was forbidden to Congress as an exercise of judicial power, the same matter having been under consideration in a federal court before the congressional proceeding was commenced. Mr. Justice Miller, speaking for the Court, said:

[W] e are sure that no person can be punished for contumacy as a witness before either House, unless his testimony is required in a matter into

36103 U.S. 168 (1881). See also Marshall v. Gordon, 243 U.S. 521 (1917), in which the Court granted a petition for writ of habeas corpus on the ground that the House lacked power to conduct what was in the circumstances of the case a criminal proceeding. The decision was based on a separation-of-powers argument in partial reliance on Kilbourn. Cliristoffel v. United States, 338 U.S. 84 (1949), is the only other case prior to Rumely in which the Court set aside a contempt conviction, holding there that a conviction could not lie under REv. STat. \$ 102 (1875), as amended, 2 U.S.C. \$ 192 (1958), for an alleged contempt before less than a quorun of the charging committee. But see Urited States v. Bryan, 339 U.S. 323 (1950).

Section 192 of title 2 reads as follows:

Every person who having been suminoned as a witness by the authority of either House of Congress to give testimony or to produce papers upon any matter of inquiry before either House, or any joint committee established by a joint or concurrent resolution of the two Houses of Congress, or any committee of either House of Congress, willfully makes default, or who, having appeared, refuses to answer any question pertinent to the question under inquiry, shall be deemed guilty of a misdemeanor, punishable by a fine of not more than $\$ 1,000$ nor less than $\$ 100$ and imprisonment in a common jail for not less than one inonth nor inore than twelve months.

37103 U.S. at 174. 
which that House has jurisdiction to inquire, and we feel equally sure that neither of these bodies possesses the general power of making inquiry into the private affairs of the citizen. ${ }^{38}$

The language is strikingly strong and apparently unambiguous; but it should be recalled that the principle there enunciated has not mandated a like result in a single subsequent Supreme Court case. To be sure, it has never been overruled, and it is regularly cited for the proposition that there are limits to the power of congressional inquiry. But by itself it offers at best fragile support for a challenge to the authority of a committee to investigate.

Kilbourn was specifically limited and "explained" in a number of later cases. In In re Chapman ${ }^{39}$ the witness, a stock broker dealing in certain sugar stocks, refused to answer questions put to him by a special Senate committee established to investigate charges that members of the Senate were yielding to corrupt influences in the consideration of proposed legislation for tariffs on sugar. Kilbourn was found to be "wholly different" because here the Senate had the "inherent power of self-protection" to inquire into charges "calculated to destroy public confidence in the body."40

More significant, because more closely parallel to the fact situation in Kilbourn, were the Court's holdings in McGrain v. Daugherty ${ }^{41}$ and Sinclair v. United States. ${ }^{42}$ In Daugherty the Senate had set up a special committee to investigate the Attorney General of the United States, Harry Daugherty, and in particular his failure to institute certain prosecutions for alleged violations of the Sherman and Clayton antitrust acts and for alleged frauds upon the Government. In the course of the investigation subpoenas were served upon the Attorney General's brother, Mally Daugherty, who ignored the summons and was thereafter arrested by the Sergeant at Arms and brought before the bar of the Senate for trial. The resulting conviction was upheld.

Plainly the subject was one on which legislation could be had and would be materially aided by the information which the investigation was calculated to elicit.

The only legitimate object the Senate could have in ordering the investigation was to aid it in legislating; and we think the subject matter was such that the presumption should be indulged that this was the real object. ${ }^{43}$

It will be observed that, although the committee's authorizing resolution

\footnotetext{
38 Id. at 190.

39166 U.S. 661 (1897).

$40 \mathrm{Id}$. at 668.

41273 U.S. 135 (1927).

42279 U.S. 263 (1929).

43273 U.S. at 177-78.
} 
did not necessarily contemplate legislation, the mere possibility that legislation might be proposed was thought sufficient to justify the committee action and to make enforceable the contempt citation.

In Sinclair the contempt proceedings arose out of a refusal to answer questions relating to the so-called Teapot Dome oil leases on the ground that the inquiry was forbidden because it related to private affairs and was not in aid of legislation. As in Daugherty the Court answered that the affairs were not merely private and that Congress could indeed inquire into leasing arrangements for public lands. Moreover, the Court concluded that the investigation "might directly aid in respect of legislative action." Nor did it matter that any information secured might also be "of use" in pending suits so long as disclosures were not sought to be compelled "for the purpose of aiding the prosecution of pending suits ...."45

The Barenblatt line of cases $^{46}$ similarly suggests little limitation on permissible legislative purpose. Mr. Justice Harlan summarized that view when he said in Barenblatt that "The scope of the power of inquiry, in short, is as penetrating and far-reaching as the potential power to enact and appropriate under the Constitution."47 Certainly no less wide-ranging a conception of the investigatory power could have justified the result im that case, upholding a section 192 contempt conviction where Barenblatt had refused to answer questions about his political beliefs and associational activities as addressed to him by a subcommittee of the House Un-American Activities Committee investigating alleged Communist infiltration in the field of education.

A similarly pervasive regard for the investigatory power was likewise essential to the contempt convictions in Wilkinson, ${ }^{48}$ Braden, ${ }^{49}$ and $U$ phaus v. Wyman. ${ }^{50}$ In Wilkinson a subcommittee of the House Un-American Activities Committee, while investigating Communist infiltration into basic industries in the South and Communist propaganda activities in the South, summoned petitioner to appear before the subcommittee upon his arrival in Atlanta, the site of the hearings, where he had come to lend his support to those who opposed the conduct of the hearings. Despite considerable evidence that Wilkinson was summoned primarily because of his criticism

44279 U.S. at 295.

45 Ibid.

40 The leading case is Barenblatt v. United States, 360 U.S. 109 (1959). The others are Braden v. United States, 365 U.S. 431 (1961); Wilkinson v. United States, 365 U.S. 399 (1961); Uphaus v. Wyman, 360 U.S. 72 (1959).

47360 U.S. at 111.

48 Wilkinson v. United States, 365 U.S. 399 (1961).

49 Braden v. United States, 365 U.S. 431 (1961).

50 Uphaus v. Wyman, 360 U.S. 72 (1959). 
of the committee, ${ }^{51}$ the majority answered cooly that "it is not for us to speculate as to the motivations that may have prompted the decision of individual members of the subcommittee to summon the petitioner."152 On this point, however, comparison is indicated with the cases in which the Court has strictly protected membership lists of various NAACP local groups against state disclosure where harassment was thought by the Court -but not conceded by demanding officials- to be the purpose behind the demand. $^{53}$ In Braden the petitioner also had opposed the House UnAmerican Activities Committee, and there was in addition evidence that his antisegregation views, expressed in Kentucky, may have been "the primary reason for his being called before" the committee. ${ }^{54}$ Again the majority found sufficient legislative purpose in the fact that the subcommittee was making a legislative inquiry into Commumist Party propaganda activities in the Southern States. ${ }^{55}$ The same philosophy underlies the decision in Uphaus where New Hampshire's interest im locating subversive persons within the state was held to outweigh the individual's interest in associational privacy.

In early 1963, apart from Kilbourn, whose loose generalities were apparently never very influential, it seemed clear that the legislative purpose argument, at least in the conventional sense of barring all inquiry, was not

51 Wilkinson v. United States, 365 U.S. 399, 415-18 (1961) (Black, J., dissenting); id. at 429-30 (Brennan, J., dissenting).

$52 I d$. at 412 .

53 NAACP v. Button, 371 U.S. 415 (1963); Louisiana v. NAACP, 366 U.S. 293 (1961); Shelton v. Tucker, 364 U.S. 479 (1960); Bates v. Little Rock, 361 U.S. 516 (1960); NAACP v. Alabama, 357- U.S. 449 (1958); cf. Gibson v. Florida Legislative Investigation Comm., 372 U.S. 539 (1963).

Shelton v. Tucker is particularly instructive. The Arkansas statute there challenged required every teacher, as a condition of employment in a state-supported school or college, to file annually an affidavit listing every organization to which he had belonged or regularly contributed during the preceding five years. By a vote of five to four the statute was invalidated because of the deprivation of associational freedom. In the majority opinion $\mathrm{Mr}$. Justice Stewart cited Sweezy v. New Hampshire, 354 U.S. 234, 250 (1957), for the proposition that "Teachers and students must always remain free to inquire, to study and to evaluate." But Mr. Justice Harlan, dissenting, found an adequate legislative purpose for the disclosure requirement here in the earhier decisions of Barenblatt and $U$ phaus. It is interesting to note, too, that in Louisiana v. NAACP the Court unanimously continued a temporary injunction against state enforcement of a statute requiring each nontrading association to file an annual affidavit that no offece of any affliated out-of-state organization was a member of any Communist, Communist-front, or subversive organization. The decision in Bates $v$. Little Rock was also unanimous in striking the compulsory disclosure of membership lists of a local branch of the NAACP.

On the other hand, when membership lists are demanded from politically unpopular organizations, the result is likely to be different, at least if there are no overtones of racial discrimination. Communist Party v. Subversive Activities Control Bd., 367 U.S. 1 (1961); New York ex rel. Bryant v. Zimmerman, 278 U.S. 63 (1928). See also Frantz, The First Amendment in the Balance, 71 YaLE L.J. 1424, 1441-42 (1962).

54 Braden v. United States, 365 U.S. 431, 439 (1961) (Black, J., dissenting).

55 Id. at 435 . 
of great importance in limiting the permissible range of topics into which committees might investigate. ${ }^{66}$ There is, lowever, another sense in which the legislative purpose doctrine may impose a more significant limitation. Mr. Justice Harlan noted this limitation in Barenblatt when le observed that Congress "cannot inquire into inatters whicl are within the exclusive province" of one of the other branches of the Governinent. ${ }^{57}$ That was wliat was ultimately at issue in Kilbourn v. Thompson, where the Court denied the contempt on the separation-of-powers ground that the attenipt to establislı wrongdoing "was in its nature clearly judicial." also made in Watkins in denying the power "to expose for the sake of exposure." And it seems again to have been a factor in Gibson v. Florida Legislative Investigation Comm. ${ }^{60}$ In that case the Court reversed a state court contempt conviction based upon the refusal of an NAACP official to bring membership lists to the learing in order to refresh his memory as to whether particular individuals were members. The Court lield that the committee liad "laid no adequate foundation for its direct demands upon the officers and records of a wholly legitimate organization for disclosure of its membership; the Committee ... [lad] neither demonstrated nor pointed out any threat to the State by virtue of the existence of the N.A.A.C.P. or the pursuit of its activities ... ."11 While clearly the result was influenced by the potential infringement upon associational riglits, the absence of legislative purpose in the sense just indicated was also relevant to the result.

No matter low legislative purpose is defined, and despite the fact that all members of the Court agree that the first amendment imposes soine limitation on an otherwise proper investigation, there is no escaping the crucial division between the opposing judicial viewpoints. It is nothing less than whether the prolibitions of the first amendment may be balanced away or not. The majority lias concluded that they may, wlile the dissenters have strongly urged the contrary. ${ }^{62}$

56 The somewhat related void-for-vagueness argument has also not met with much success. Despite dictum in Watkins to the effect that rule XI, the charter of the House Un-American Activities, might be defective in this respect, 354 U.S. at 209 , the argument was specifically rejected in Barenblatt, 360 U.S. at 116-23. In any event, the argument is not central because the authorizing resolution could readily be amended to satisfy the requirement of particularity.

57360 U.S. at 112.

58103 U.S. 168, 192 (1881).

59354 U.S. 178, 200 (1957). See also Deutch v. United States, 367 U.S. 456 (1961); Umited States v. Cross, 170 F. Supp. 303 (D.D.C. 1959); United States v. Icardi, 140 F. Supp. 383 (D.D.C. 1956).

60372 U.S. 539 (1963).

01 Id. at 555 .

62 Compare Frantz, The First Amendment in the Balance, 71 Yale L.J. 1424 (1962), with Mendelson, On the Meaning of the First Amendment: Absolutes in the Balance, 50 CarrF. I. REv. 821 (1962). 
Discussion of the "balancing" controversy has often identified the opposing views in terms of Mr. Justice Black's "absolutes" sometimes assumed to be the polar opposite, a substantial deference to legislative judgment, as advocated by $\mathrm{Mr}$. Justice Frankfurter ${ }^{04}$ and by Judge Learned Hand. ${ }^{65}$ But this is at least in part misleading. Any judgment involves an element of comparing or weighing opposing values, ${ }^{\circ 6}$ and at least in this sense all members of the Court indulge in some balancing of competing social interests in certain types of first amendment cases. ${ }^{07}$

Balancing in relation to first amendment rights got off to a comparatively easy and noncontroversial beginning in Schneider v. Irvington ${ }^{08}$ and Cantwell v. Connecticut, ${ }^{69}$ in both of which the right of a city to control the use of its streets was at issue. Schneider involved an ordinance prohibiting the distribution of handbills in order to prevent littering. Although enforcement of the ordinance was forbidden as to literature concerned with ideas, the Court found it appropriate to "weigh the circumstances." In Cantwell, where the defendant had been convicted of breach of the peace for playing a phonograph on the street, the Court upheld as a defense the right to disseminate religious views. But in so doing the Court stated that a city could "by general and non-discriminatory legislation regulate the times, the places, and the manner of soliciting upon its streets and holding meetings thereon."71

There is, however, a fundamental difference between the use of balancing concepts in cases only indirectly affecting speech (where the scales are in any event weighted in favor of the first amendment by the preferred

63 See Black, The Bill of Rights, 35 N.Y.U.L. REv. 865 (1960). See especially Mr. Justice Black's dissents in Wilkinson v. United States, 365 U.S. 399, 415 (1961), and Barenblatt v. United States, 360 U.S. 109, 134 (1959).

64 See, e.g., Mr. Justice Frankfurter's concurring opinion in Dennis v. United States, 341 U.S. 494, 525 (1951).

${ }^{65}$ See HaNd, The Bint of Rights (1958).

66 First amendment freedoms may be involved on both sides of a controversy. For example, identification of the sources of published materials serves the interest of the public as a disclosure device of full information, but may work to the disadvantage of the individual compelled to relinquisb his anonymity perhaps at the expense of public or private harassment. Compare Talley v. California, 362 U.S. 60 (1960), with Viereck v. United States, 318 U.S. 236, 251 (1943) (dissenting opinion).

67 See Watkins v. United States, 354 U.S. 178, 198-99 (1957). Mr. Justice Black has outlined the limited circuinstances in which lie would approve balancing. "[A] law which primarily regulates conduct but which might also indirectly affect speech can be upleeld if the effect on speech is minor in relation to the need for control of the conduct." Barenblatt v. United States, 360 U.S. 109, 141 (1959).

68308 U.S. 147 (1939).

69310 U.S. 296 (1940).

70308 U.S. at 161.

71310 U.S. at 304. See also Marsh v. Alabama, 326 U.S. 501 (1946). 
position it occupies ${ }^{72}$ ) and the use of balancing in cases involving "a law directly aimed at curtailing speech and political persuasion"73 (and then weighting the scales against free speech and in favor of legislative judgment). It is one thing to seek first a definition of the area which is within the scope of constitutional protection and then to accord absolute immunity to speech and assenibly within that area; and it is sonrething quite apart to say that in every case there can be balancing, with the scales to be newly adjusted each time. Inevitably, where such ad hoc balancing is permitted, freedom of speech is denied any fixed content.

It is defined only by the weight of the interests arrayed against it and it is inversely proportional to the weight accorded to those interests. When this approach is taken, there can be no floor beneath which that freedom may be allowed to sink. No matter how low it may fall, we must always be prepared to see it fall still further if the needs of "security" increase-or if an atmosphere of fear and hysteria makes them seem to increase. ${ }^{74}$

In the specific context of legislative investigations Mr. Justice Black made the point thus:

The truth of the matter is that the balancing test, at least as applied to date, means that the Committee may engage in any inquiry a majority of this Court happens to think could possibly be for a legitimate purpose whether that "purpose" be the true reason for the inquiry or not. ${ }^{75}$

Indeed, the real truth seems to be that, if the balancing test is applied, the first amendment is drained of all meaning except to say that government should not act unreasonably. ${ }^{76}$ But surely it was not the original intent that the first amendment should mean nothing different than the due process protection against arbitrary and unreasonable governmental action.

\section{II}

\section{SELF INCRIMINATION AND FREE SPEECH}

When congressional committees inquiring into political beliefs and associational activities deplore the unavailability to them of testiniony that is barred by the privilege against self incrimination, they should remember what it is that inakes of that plea "the ultimate protection"77 for a witness who seeks justification for his refusal to answer committee questions.

72 See McKay, The Preference for Freedom, 34 N.Y.U.L. REv. 1182 (1959).

73 Barenblatt v. United States, 360 U.S. 109, 142 (1959) (Black, J., dissenting).

74 Frantz, supra note 62, at 1442-43.

75 Wilkinson v. United States, 365 U.S. 399, 420 (1961) (dissenting opinion).

78 Barenblatt v. United States, 360 U.S. 109, 143 (1959) (Black, J., dissenting).

77 Redlich, Rights of Witnesses Before Congressional Committees: Effects of Recent Sitpreme Cout Decisions, 36 N.Y.U.L. REv. 1126, 1127 (1961). 
Resort to the privilege was made possible-and defensively necessaryfor Communists, former Communists, and those who might be thought because of their associations to have been Communists, as a result of Supreme Court decisions that some political affiliations are more dangerous than others, and that certain activity in support of such ideologies could be subjected to criminal punishment. ${ }^{78}$ The above-discussed decisions which make reliance on the first amendment appear to be unavailing, in combination with those which allow resort to the privilege against self incrimination, make it clear that the reluctant witness has no choice but to use the defense likely to succeed. In short, the very decisions which were widely approved by congressional committees concerned with investigating subversion have a built-in boomerang in that the danger of incrimination, which they demonstrate lies in admissions of meinbership (or near membership) in Communist organizations, nuakes secure the plea of self incrimination as an absolute bar to answers to questions concerning such inembership. Mr. Justice Harlan made it perfectly explicit that the fifth amendment is a safe refuge while the first amendnent is at best chancy when he said that "the protections of the First Amendment, unlike a proper claim of the privilege against self-incrimination under the Fifth Amendment, do not afford a witness the right to resist inquiry in all circumstances." $" 70$

Surely there is irony in downgrading the proudly affirmative claims of the first amendment to a position inferior to the merely negative implications of the fifth anrendment. But that is indisputably the case. While the Court was appreciably diluting the cominand of the first amendment in Barenblatt, Wilkinson, and Braden, it was at the same time making more secure the fifth amendment plea of the privilege. What interpretative doubts inhere in the text of the guarantee of the privilege against self incrimination have ordinarily been resolved in favor of a generous recognition of the right to remiain silent in the face of any official questioning by federal officers where a truthful answer might lead to criminal prosecution.

It was long assumed that the privilege as thus construed was available to witnesses before congressional investigating comnittees; and committees, during the McCarthy period and before, were accustomed to honoring any specific invocation of the privilege. But it was not until the decisions in Quinn, ${ }^{80}$ Emspak, ${ }^{81}$ and Bart $^{82}$ that it was made absolutely clear

78 Scales v. United States, 367 U.S. 203 (1961) ; Communist Party v. Subversive Activities Control Bd., 367 U.S. 1 (1961) ; Dennis v. United States, 341 U.S. 494 (1951); American Communications Ass'n v. Douds, 339 U.S. 382 (1950) ; cf. Yates v. United States, 354 U.S. 298 (1957).

79 Barenblatt v. United States, 360 U.S. 109, 126 (1959).

80 Quinn v. United States, 349 U.S. 155 (1955).

81 Enıspak v. United States, 349 U.S. 190 (1955).

82 Bart v. United States, 349 U.S. 219 (1955). 
how wide was the range of fifth-amendment protection available to reluctant witnesses before congressional committees. Thus, in Quinn a refusal to answer based on "the first and fifth amendments" was held sufficient to avoid the contempt conviction because the self-mcrimination clause "must be accorded liberal construction in favor of the right it was intended to secure." ${ }^{\prime 83}$ In Bart, despite an unequivocal refusal to answer, the Court denied the contempt conviction because the committee failed to give petitioner "a clear-cut ruling" as to whether his loosely framed fifth-amendment objection was accepted or rejected. ${ }^{84}$

Meanwhile, in other cases not involving congressional investigations, the work of expanding the scope of the privilege against self incrimination was carried forward under the impulse of the Supreme Court. ${ }^{85}$ The most important case was Hoffman v. United States, ${ }^{86}$ in which the Court laid down a simple imperative.

To sustain the privilege, it need only be evident from the implications of the question, in the setting in which it is asked, that a responsive answer to the question or an explanation of why it cannot be answered might be dangerous because injurious disclosure could result. ${ }^{87}$

The broad reach of the privilege is limited somewhat, however, by virtue of three subsidiary propositions.

1. The dual sovereignties rule permits testimony compelled by one sovereign, pursuant to a grant of immunity from prosecution by that sovereign, to be freely used in a criminal prosecution by another sovereign.$^{88}$ As Mr. Justice Black has expressed the result, "a person can be whipsawed into incriminating himself under both state and federal law even though there is a privilege agamst self-incrimination in the Constitution of each."189 Moreover, the Court has upheld statutes requiring the giving of testimony that would otherwise be exempt, upon a statutory assurance of immunity

83 Quinn v. United States, 349 U.S. 155, 162 (1955), quoting from Hoffman v. United States, 341 U.S. 479, 486 (1951). To similar effect see Emspak v. Umited States, 349 U.S. 190, 193 (1955), where petitioner based his refusal to answer on "primarily the first amendment supplemented by the fifth."

84 Bart v. United States, 349 U.S. 219, 221-22 (1955).

85 For a discussion see Redlich, supra note 77, at 1127-36.

86341 U.S. 479 (1951).

87 Id. at 486-87. The same rule applies in connection with a demand for the production of personal records, disclosure of whicl miglit tend to incriminate; but the privilege does not extend so far as to protect against disclosure of records held in a representative capacity. United States v. White, 322 U.S. 694 (1944). See also Curcio v. Umited States, 354 U.S. 118 (1957).

88 Knapp v. Schweitzer, 357 U.S. 371, 380 (1958) ; Feldman v. United States, 322 U.S. 487, 492 (1944); United States v. Murdock, 284 U.S. 141, 148 (1931); Jack v. Kansas, 199 U.S. 372,380 (1905).

89 Knapp v. Schweitzer, 357 U.S. 371, 385 (1958) (dissenting opinion). 
from prosecution by the government, nation or state, so demanding disclosure. ${ }^{90}$

2. Although the Supreme Court has insisted categorically that no inference of guilt may be made as to one who invokes the privilege against self incrimmation, ${ }^{91}$ the Court has nonetheless been willing to permit the imposition of severe economic penalties upon those who invoke the privilege. It is not, so runs the rationale, because of the claim of the privilege, but because the refusal to answer questions deemed appropriate may be regarded as evidence of incompetence, of lack of candor where there is a duty to disclose fully, or of unwillingness to supply information relevant to a judgment of fitness. ${ }^{92}$

3. A principal explanation for the fact that the privilege has been so often invoked in response to seemingly innocuous questions lies in the fact that a voluntary answer to one question may trigger the waiver principle so that the privilege becomes unavailable in response to other questions relating to the same subject matter. ${ }^{93}$

The leading Supreme Court decision on waiver is United States $v$. Rogers, ${ }^{94}$ in which the witness had admitted before a grand jury that she had been an official of the Colorado Communist Party, but thereafter refused to tell the name of the person to whom she had turned over party records, pleading the privilege against self incrimination. The finding of waiver was based on the theory that the witness had already incriminated herself and therefore could not stop short of full disclosure. But the dissenters, Justices Black, Frankfurter, and Douglas, challenged the priorcrimination principle, noting that additional questions could well have incriminated further or could have provided additional leads in support of the incriminating statements already made. However applicable the prior-crimination reasoning may be in adversary proceedings as a justification for requiring full disclosure on the basis of a fictive waiver, it scarcely seems meaningful in the context of congressional investigations which are not adversary but inquisitory. In adversary proceedings there is of course some logic in declining to permit a witness to give only answers favorable to him while he refuses to answer related questions that might help his

90 Ullmann v. United States, 350 U.S. 422 (1956). See also Reina v. United States, 364 U.S. 507 (1960). For a discussion of the Inununity Act of 1954, 18 U.S.C. $\$ 3456$ (1958), see TAYLOR, Grand Inquest 243-47 (Ballantine ed. 1961); Comment, 53 Mich. L. Rev. 858 (1955).

01 Slochower v. Board of Educ., 350 U.S. 551, 557-58 (1956). See also Ullmann v. United States, 350 U.S. 422, 426-28 (1956); Gruswold, The Firtil Amendment Today (1956).

92 Cohen v. Hurley, 366 U.S. 117 (1961); Nelson v. County of Los Angeles, 362 U.S. 1 (1960) ; Lerner v. Casey, 357 U.S. 468 (1958) ; Beilan v. Board of Educ., 357 U.S. 399 (1958).

${ }^{83}$ See Zeserson, Fifth Amendment Waiver in Congressional Investigations, 18 N.Y.U. INTRA. L. REv. 62 (1962).

94340 U.S. 367 (1951). 
adversary. So there is force in the position that a witness in adversary proceedings must answer all questions or none concerning a single series of events. But if legislative investigations are justified in terms of fact finding for a legislative body, the risk of unfairness to an "adversary" dwindles to insignificance. ${ }^{95}$ Moreover, the doctrine creates for witnesses a difficult dilemma which $\mathrm{Mr}$. Justice Black outlined as follows:

On the one hand, they risk imprisonment for contempt by asserting the privilege prematurely; on the other, they might lose the privilege if they answer a single question. The Court's view makes the protection depend on timing so refined that lawyers, let alone laymen, will have difficulty in knowing when to claim it. ${ }^{96}$

The Rogers case led to further waiver problems in connection with demands for the production of records. In the context of that case the Court did not liave to decide whether the privilege attaches to questions concerning the location of records which, as records of an organization, are not themselves privileged. ${ }^{97}$ In Curcio v. United States, ${ }^{98}$ in which that issue was presented, the Court upheld a claim of privilege by the custodian of organizational records when asked their whereabouts, after he had stated that the records were not then in his possession. The Court concluded that the witness was in danger of further incrimination even though he had already disclosed his relationship to the records.

Confusion is not lessened by the decision in $M c$ Phaul v. United States. ${ }^{99}$ $\mathrm{McPhaul}$, the presumed executive secretary of the Civil Rights Congress, was commanded by the House Un-American Activities Committee to produce all organizational and financial records of the Civil Rights Congress. Apparently in reliance on Curcio he pleaded the privilege and refused to produce the records or to offer any explanation. But this time the Court upheld the conviction for his failure to produce or give any explanation for the nonproduction. Froin these facts the Court found an inference that he could have produced the records, so "the burden then shifted to the petitioner to present some evidence to explain or justify his refusal."100 The four dissenters complained that this took away the presumption of innocence and reduced the privilege in these circunstances to empty ritual. ${ }^{101}$ This was said to be the case because under the majority ruling the burden was shifted to the witness to show that he was not an officer or agent of

05 For a more complete argument to this effect, see Zeserson, supra note 93.

98 United States v. Rogers, 340 U.S. 367,378 (1951) (dissenting opinion).

87 See Redlich, supra note 77, at 1132.

98354 U.S. 118 (1957).

90364 U.S. 372 (1960).

100 Id. at 379.

101 Id. at 383 . The dissenting opinion of Mr. Justice Douglas was joined by Chief Justice Warren and Justices Black and Brennan. 
the organization and that he was unable to produce the documents, despite the fact that the prosecution had not offered proof to connect him with the organization or with the documents. That, they said, was "like taking his action in standing mute as a confession of guilt." 102

In the light of these cases the dilemma of the witness unable or unwilling to produce records would seen to be this: He must be "guided by the $M c P h a u l$ case which commands hin to offer an explanation, the Curcio case which permits hin to stop explaining at some point, and the Rogers case which warns him that his words night constitute a waiver of the privilege."103

\section{III}

\section{EXECUTIVE PRIVILEGE AND SEPARATION OF POWERS ${ }^{104}$}

In a paper purporting to discuss Supreme Court decisions relating to congressional investigations the discussion of the executive privilege could be exceedingly brief; for there have been no Suprene Court decisions. Apparently, there have been no court decisions of any kind either upholding or denying the right of the executive branch to refuse answers or docunients demanded by congressional committees. The question has been raised during practically every presidential administration, and in especially acute form in recent years where the executive branch has withheld information in such celebrated nistances as the Army-McCarthy disputes, the Dixon-Yates contract hearings, the foreign aid investigations, the Federal Einployees' Security Prograin incidents, the U-2 incident, the Antitrust Consent Decree Program of the Department of Justice, the burning of the farm population pamphlets, and the investigation into the award of the TFX contract. ${ }^{105}$ There have even been investigations into the

102 Id. at 386. See also Presser v. United States, 284 F.2d 233 (D.C. Cir. 1960), cert. denied, 365 U.S. 816 (1961), where the witness did explain his failure to produce all the records demanded. He had, he said, furnished all he could gather together. When he refused to state whether he had destroyed any of the records, pleading the privilege, he was convicted of contempt on the ground of waiver. Subsequently Presser was also convicted for mutilating and concealing the records he failed to produce. Presser v. Umited States, 292 F.2d 171 (6th Cir. 1961), affd by equally divided Court, 371 U.S. 71 (1962) (Goldberg, J., not participating).

103 Redlich, supra note 77, at 1134.

104 For a comprehensive treatment and a detailed exaunination of practice, see Kramcr \& Marcuse, Executive Privilege-A Study of the Period 1953-1960 (pts. 1-2), 29 Gzo. WAsr. L. Rev. 623, 827 (1961). See also Bishop, The Executive's Right of Privacy: An Unresolved Constitutional Question, 66 Yare L.J. 477 (1957); Schwartz, The Papers of the Executive Branch, 45 A.B.A.J. 467 (1959); Younger, Congressional Investigations and Execative Secrecy, 20 U. PITT. L. REv. 755 (1958-1959).

105 For interesting accounts of all of these except the last, see Kramer \& Marcuse, stupra note 104 , at $668-717,827-92$. 
power of the executive branch to withhold information. From these latter inquiries came legislation designed to insure that the already-existing "housekeeping" statute not be thought to be a basis for a general power to refuse congressional demands. ${ }^{106}$

Nowhere in the Constitution is there express sanction for the executive branch to withhold imformation sought by Congress or, for that matter, by the courts. Nor, on the other hand, is there express sanction in the Constitution for the legislative investigation or for judicial demands upon the executive. As in other instances in which appeal is made to the "unwritten" Constitution, extravagant claims have been made on both sides of the controversy between the executive branch on the one hand and the congressional and judicial branches on the other. In an unbroken line of opimions by Attorneys General of the United States the executive privilege has been sustained as "an inherent part of our Government, based upon the separation of powers, and ... recognized from the beginning of our Government."107 On the other hand, claims have not infrequently been made in Congress that the executive privilege is nonexistent or, at the very least, that the investigatory power should be regarded as superior in any contest between the two. ${ }^{108}$

This potentially explosive dispute between the executive and legislative branches has not been resolved in the courts; moreover, it is unlikely that it will be effectively dealt with there; ${ }^{109}$ and perhaps the resolution

106 Id. at 893-94. Prior to amendment the statute had read: "The head of each department is authorized to prescribe regulations, not inconsistent with law, for the government of his department, the conduct of its officers and clerks, the distribution and performance of its business, and the custody, use, and preservation of the records, papers, and property appertaining to it." REv. Stat. $\$ 161$ (1875), as amended, 5 U.S.C. $\$ 22$ (1958).

The one-sentence addition in 1958 provided as follows: "This section does not authorize withholding information from the public or himiting the availability of records to the public." 72 Stat. 547 (1958), 5 U.S.C. $\$ 22$ (1958).

The Senate report on the bill stated that the bill was intended to prevent abuse of the existing statute, but emphasized that the amendment was not

intended to affect, what the Attorney General describes as an "Executive privilege" to withhold information from the Congress and the public.

To wbatever extent such an "Executive privilege" exists, it inust be founded on the principle of separation of powers under the Constitution and, accordingly, will not be repealed, amended, or impaired by the proposed amendment. . . .

S. REP. No. 1621, 85th Cong., 2d Sess. 6 (1958).

107 Testimony of Attorney General Rogers in March 1958, Freedom of Information and Secrecy in the Government, Hearing on S.921 Before the Subcommittee on Constitutional Rights of the Senate Committee on the Judiciary, 85th Cong., 2d Sess. 26 (1958).

108 See H.R. Rep. No. 1137, 86th Cong., 1st Sess. 400 (1959); Kramer \& Marcuse, supra note 104 , at $898-900$.

109 The matter is unlikely to reach the courts unless Congress seeks to enforce a contempt citation against a member of the executive branch, either pursuant to sections 192 and 194 of title 2 of U.S.C., or by trial before the bar of one of the Houses. So far this show of strength has been avoided, and happily so. See Kramer \& Marcuse, supra note 104, at 903-04. 
should in any event be left to the political process, of which it is after all a part. ${ }^{110}$

Certainly no one denies that Congress possesses the power to investigate performance by the executive branch of functions committed to it by Congress, or functions inherently part of the executive authority for which Congress has appropriated funds. ${ }^{111}$ It is equally clear that the executive has some power to withhold information in the proper exercise of executive functions as required by the conduct of foreign or military affairs. The Supreme Court has recognized as much in the closely parallel question of the right of the executive to withhold information in judicial proceedings. ${ }^{112}$ Congress itself has repeatedly recognized and respected the existence of the executive privilege. ${ }^{113}$ It may well be that the executive has been overprotective of its files and overly sensitive about testimony by its officials and enployees both in connection with judicial proceedings ${ }^{114}$ and congressional investigations; ${ }^{115}$ but abuses in the judicial arena can be dealt with effectively by the courts through procedures available under the Federal Rules of Civil and Criminal Procedure, including discovery and other devices for disclosure of relevant inaterial. ${ }^{116}$ Nor is Congress helpless when confronted with an unreasonable withholding by the executive. The power to enact or refuse legislation desired by the Administration, the power to appropriate or not, and the power to confirn or not are potent weapons whose effective deployment congressmen may be expected to understand. In addition, Congress has indulged in effective sloganizing by asserting its demands in vindication of the "people's right to know,",117 thus inevitably eliciting support from a substantial segment of the press.

110 Professor Bíshop suggests that "a good case can be made out for the proposition that the present imprecise situation is, in fact, reasonably satisfactory. Neither the executive nor the Congress is very sure of its rights, and both usually evince a tactful disposition not to push the assertion of their rights to abusive extremes. Of such is the system of checks and balances." Bishop, The Executive's Right of Privacy, 66 Yale L.J. 477, 491 (1957).

111 See text accompanying notes 46-52 supra.

112 See, e.g., United States v. Reynolds, 345 U.S. 1 (1953); United States ex rel. Touhy v. Ragen, 340 U.S. 462 (1951); Boske v. Comingore, 177 U.S. 459 (1900); cf. Appeal of the SEC, 226 F.2d 501 (6th Cir. 1955).

113 See Kramer \& Marcuse, supra note 104, at 900-02.

114 Professor Hardin makes this poimt effectively in his article, Executive Privilege in the Federal Courts, 71 Yate L.J. 879 (1962).

115 Certainly the Hennings and Moss committees thought so. See materials cited in Kramer \& Marcuse, supra note 104, at 893 nn.764-66.

116 FED. R. Crv. P. 26-37; FEd. R. Cros. P. 16. See also the amendment to rule 16 and the new rule 12A proposed by the Advisory Committee on Criminal Rules of the Committee on Rules of Practice and Procedure of the Judicial Conference of the Unitcd States, reported December 15, 1962. 83 Sup. Ct., No. 8 (Feb. 15, 1963).

117 See, e.g., Cross, The Propres' Rught to Know (1953); Hennings, The Executive Privilege and the Peoples' Right to Know, 19 FED. B.J. I (1959). 
If, as here suggested, the right of investigation and the executive privilege are both values of importance to the system, and both of equal constitutional dignity, it is probably fortunate that the courts have been able to avoid what would have necessarily been ad hoc insertions of judicial authority into this tendentious area. A not unreasonable accommodation has been worked out by the political process. To say that still better adjustment should be sought, and may be achieved even within the political context, ${ }^{118}$ is not to say that the courts could do better, or even as well.

\section{CONCLUSIONS AND PROSPECTUS}

In seeking to appraise the current state of Supreme Court doctrine on a topic as much in process of reformulation as that of congressional investigative authority, a commentator invariably regrets that he does not have available the decision in just one more then-pending case. As this is written in the spring of 1963, that case is Yellin v. United States. ${ }^{119}$ It is not so much that the case presents distinctly different issues from Watkins, Barenblatt, Wilkinson, and Braden, for in the main it does not. Rather its potential importance lies in the fact that the Court was closely divided in all those cases and that two of the majority justices in the last three of the above-named cases, Justices Frankfurter and Whittaker, have been replaced on the Court by Justices Goldberg and White, whose views on these issues have not been stated. Such hints as there are will be noted below, but first it seems appropriate to draw a few general conclusions from the matters above discussed.

1. To say the obvious at once, and get it out of the way, the congressional investigations in oversight of legislation already enacted, in review of pending legislative proposals, and in aid of legislation that might (or might not) be proposed, but is within the power of Congress to enact, are properly part of the legislative power, have always been recognized as such, and should be so regarded. Perhaps less obvious, but equally true, is the proposition that the "private affairs" limitation stated in Kilbourn is of little practical significance as a limitation. Although routinely adverted to in nearly all subsequent cases, it has not since 1881 in the Kilbourn decision itself been the basis for another decision; and it appears unlikely that it will be revived as an effective limitation on congressional authority.

118 See Kramer \& Marcuse, supre note 104, at 909-16.

119287 F.2d 292 (7th Cir.), cert. granted, 368 U.S. 816 (1961) (No. 477, 1961 Term; renumbered No. 35, 1962 Term). See also United States v. Shelton, 369 U.S. 759 (1962), and the analysis by Mr. Bendich, First Amendment Standards for Congressional Investigation, 51 Carif. L. Rev. 311 (1963). 
With the expansion of congressional legislative power in recent decades, even if there may be some specific pieces of legislation which Congress may not enact, there may well be no subject matter on which Congress could not be deemed to have some regulatory power. While it is probably true that the legislative-purpose limitation, in the separation-of-powers sense, retains vitality to restrain intrusion into the domain of the judiciary, legislative purpose should not be looked to as more than a very limited check upon congressional investigative power.

2. Although the Supreme Court has been unwilling to limit the investigatory power on conventional legislative-purpose grounds, at least since 1949 the Court has been demonstrably ready to examine the exercise of the power with sometimes exacting standards of particularity. Thus, in Christoffel the defect was absence of a quorum; ${ }^{120}$ in Rumely difficulty was found with the committee authorization from Congress; ${ }^{121}$ in Watkins, Sweezy, Sacher, and Deutch the particular questions asked were not pertinent to the subject under inquiry; ${ }^{122}$ in Quinn, Emspak, Bart, Flaxer, and Slagle the committee did not make sufficiently clear the direction to answer a question or to produce documents; ${ }^{123}$ in Russell the indictment was defective in failing to identify the subject of the inquiry; ${ }^{124}$ and in Gibson no sufficient foundation was laid to show a connection between the subject matter of the inquiry and the organization sought to be investigated. ${ }^{125}$

It is apparent that each of these investigative pitfalls can be cured by a prudent committee staff and that no enduring principles of limitation have been imposed upon the investigatory process as a result of these decisions. Yet cumulatively they are important, for in each of these cases there was also raised a first amendment (and in some a fifth amendment) issue. Quite obviously the Court is moved to search out these technical flaws of procedure because of the lurking constitutional problem which has apparently not yet been resolved to the satisfaction of the Court. That question is of course: Can the first amendment be pleaded as a basis for refusal to answer committee questions that require disclosure of political

120 Christoffel v. United States, 338 U.S. 84 (1949).

121 United States v. Rumely, 345 U.S. 41 (1953).

122 Watkins v. United States, 354 U.S. 178 (1957); Sweezy v. New Hampshire, 354 U.S. 234 (1957); Sacher v. United States, 356 U.S. 576 (1958); Deutch v. United States, 367 U.S. 456 (1961).

I23 Quinn v. United States, 349 U.S. 155 (1955); Emspak v. United States, 349 U.S. 190 (1955); Bart v. United States, 349 U.S. 219 (1955); Flaxer v. United States, 358 U.S. 147 (1958); Slagle v. Ohio, 366 U.S. 259 (1961).

124 Russell v. United States, 369 U.S. 749 (1962).

125 Gibson v. Florida Legislative Investigation Comm., 372 U.S. 539 (1963). 
beliefs or associational activities? It is unfortunate that the issue nearly always arises in the context of the discredited Communist Party, thus raising emotional considerations that would not be present if the cases for decision involved more conventional political affiliations, or if the question related to religious belief. We may assume that questions about religious belief would be so unthinkable that a refusal to answer would be protected as a matter of course. Equally, it is difficult to imagine a question about membership in the Republican or Democratic Parties because it seems so clearly irrelevant. And we know that the Court examines with extra care claims that associational freedoms are threatened on grounds of racial discrimination. ${ }^{126}$ But is not that the very point? If the first amendment does not protect unpopular beliefs and association with minority groups, it stands for nothing. Members of majority groups in society scarcely require protection from the nonconformist members of society through compelled disclosure of the political beliefs and associational ties of nonconforming individuals and groups. Surely the heritage of first amendment freedoms should not be so lightly balanced away.

3. In the absence of constitutionally protected reliance on the first amendment as a basis for refusing to answer questions into belief and organizational affiliation, the privilege against self incrimination has been elevated to a status of "absoluteness" ironically denied to the freedoms of the first amendment. With reversal of the "preferred position" of the first amendment so that it becomes in the context of legislative investigation a second-class right, the fifth amendment has come to serve as an almost complete barrier to committee inquiry into belief and association. The privilege is almost invariably available to a witness who is questioned about allegedly subversive activities; and committees are denied all such testimony except by those few who stand on the principle of the first amendment alone, although the fifth would also be clearly available. Values seem terribly upended when the negative claim of crimination is preferred to the more affirmative reliance on first amendment freedoms.

Thus regarded, the question is not one of making more or less information available to investigating committees; for in truth the information at issue can be withheld in any event. The relevant question is as to whether the withholding should be permitted for the real reason, the right to privacy of belief, or wliether it must be grounded on the pseudo reason of fear of self incrimination.

4. Yellin v. United States, ${ }^{127}$ on the central issue, is a case like others that have preceded it. Also like others, it raises some peripheral issues on

${ }^{120}$ See note 53 supra and accompanying text.

127 Supra note 119. 
which decision could be based to reverse the contempt conviction without passing on the first amendment question. Edward Yellin was subpoenaed to appear on February 6, 1958, before a subcommittee of the House UnAmerican Activities Committee for a public hearing inquiring into (1) "The extent, character and objectives of Communist infiltration and Communist Party propaganda activities in basic industry in the Gary, Indiana area" in order to secure additional information relating to proposed amendments to the Communist Control Act of 1954, and (2) the enforcement by affected administrative agencies of the Communist Control Act in connection with rights and privileges under the National Labor Relations Act. These purposes were stated at the opening of the hearing on the day Yellin appeared. ${ }^{28}$ Meanwhile, however, his request by telegram that he be heard in executive session had been rejected, apparently without committee consideration despite the fact that its own rules provide for hearings in executive session where a majority of the committee or subcommittee "believes that a hearing might .... unjustly injure [the witness'] reputation ...."120 The committee apparently believed that Yellin was a Communist who had been designated to insinuate himself into a laboring community in part by falsifying an application for employment at a steel mill by failing to state that he had previously attended college for two years. ${ }^{130}$ Pursuant to an indictment that presumably satisfied the particularity requirements of Russell v. United States, ${ }^{131}$ he was convicted on four counts of refusing to answer questions relating to his residence prior to September 1957, his awareness of persons or activities in the steel unions in Gary relating to Communist "colonization," and his own membership or not in the Communist Party when he filed his application for employment in the steel mills. $^{132}$

128287 F.2d at 296.

129 Rule IV-A (1) of the Rules of Procedure of the House Un-American Activities Committee.

130 N.Y. Times, April 1, 1963, p. 48, col. 6.

131369 U.S. 749 (1962).

132 Yellin's conviction had consequences affecting the National Science Foundation and legislation affecting grants made by the Foundation. At the time of the conviction Yellin was a graduate student at the University of Illinois where he was first suspended and then reinstated after he answered questions to the satisfaction of university officials. Meanwhile, however, he had applied for a fellowship from the National Science Foundation which was awarded without the Foundation's knowledge of the earlier conviction. Yellin, who had sworn the requisite oath of allegiance and executed the necessary disclainer affidavit, was at first supported by the Foundation. But when Congress appeared about to impose a severely restrictive loyalty oath requirement for all fellowship applicants, the Foundation revoked the award. A legislative compromise was worked out requiring applicants to state criminal convictions and making it illegal for members of organizations required to register with the Subversive Activities Control Board to apply, but repealing the disclaimer affidavit. N.Y. Times, April 1, 1963, p. 48, col. 6. 
At the trial, and in argument before the Supreme Court, Yellin raised several arguments in addition to the first amendment issue. Several possibilities for decision are thus available. The Court could affirm on the basis of Barenblatt, Wilkinson, and Braden, finding the other arguments insubstantial; or it could reverse on one of the side issues, to be noted below; or it could reconsider and overrule the Barenblatt line of cases. The principal questions may be summarized as follows:

a. Did the committee violate its own rules in refusing to question petitioner in executive session? Petitioner argued that since rule IV-A(1) provides for executive session on majority vote of the subcommittee members, the request for executive session must have been presented to the subcommittee for decision, relying on Christoffel v. United States ${ }^{133}$ for the proposition that a committee may not proceed without regard to its rules. Committee chairman Congressman Walter, however, who testified under subpoena at the trial, stated that the committee had decided against an executive session at the time when it first decided to call Yellin; ${ }^{134}$ and the Government further contended that in any event rule IV-A confers no right to judicial review of the exercise of committee discretion. ${ }^{135}$ Prediction is of course hazardous; but this scarcely seems a point of sufficient merit to avoid decision of the more basic questions.

b. Was it error for the trial court to exclude expert testimony on factors that should be considered by the court in determining petitioner's rights? At the trial petitioner called Professor Thomas I. Emerson of Yale Law School to testify as an expert on the factors which should be considered by the district court in balancing the public and private interests in determining whether first amendment rights had been violated. But the proffered evidence was rejected because the court regarded it as opinion evidence on a question of law rather than one of fact. The statement was nevertheless put in the record as an offer of proof and was considered by the district court and by the court of appeals. ${ }^{136}$ Again mindful of the risk of prediction, one is nonetheless tempted to believe that this argument, too, is not substantial. However, the offer of testimony is clearly useful in eniphasizing the lack of clarity as to the nature of the balancing said to be involved in these cases. Whether fact or law, a proposition not really made clear by the balancing decisions, Professor Emerson's statement emphasized in helpful ways the difficulty of balancing and the importance of weighing on

133338 U.S. 84 (1949); cf. Service v. Dulles, 354 U.S. 363 (1957); Peters v. Hobby, 349 U.S. 331 (1955).

134 Brief for the United States on Reargunient, p. 83, Yellin v. United States, No. 35 (Sup. Ct., 1962 Term).

135 Ibid.

136287 F.2d at 298. 
the side of silence considerations more important than simply the interest of one witness in refusing to answer. ${ }^{137}$

c. Was the questioning of petitioner concerning his membership in the Communist Party and the party's "colonization" of the steel industry pursuant to a valid legislative purpose? As already suggested, there does not seem much doubt that the legislative-purpose tests consistently adhered to by the Court were satisfied by the resolutions adopted by the committee and stated at the opening of the hearing. However, that does not necessarily dispose of a somewhat separate contention in the case. There was

137 The Emerson statement is summarized in the Brief for the United States on Reargument, supra note 134 , at 72-75.

Professor Emerson testified that the government's interest in seeking information from petitioner was to pass leyislation protecting against overthrow of the government by force and violence (R. 100). He stated that in weighing this interest the court should consider six factors. First, present statutes (which he described) already performed this purpose. Second, the country was strong economically, politically, and socially. Prosperity, according to Professor Emerson, made an economic collapse unlikely; no strong radical groups existed which constituted a danger to internal security, particularly since there was no indication that the police or military were sympathetic to attempts to overthrow the government; and there was no serious social unrest (R. 103). Third, Professor Emerson testified, the Communist Party was extremely weak in 1958 both in numbers and positions of importance; security programs prevented the infiltration of government and industry; and Communist power in labor unions, religious and educational institutions, and the Negro community was extremely small (R.103-106). The fourth factor in determining the government's interest was the activity of the A.F.L.-C.I.O. and other unions in preventing Communist infiltration of labor (R. 106-107). Fifth, Professor Emerson stated that the House Un-American Activities Committee, as shown by its reports, already "had taken substantial testimony on the questions that they addressed themselves to in the Gary proceedings" (R. 107). And, finally the Committee could obtain substantial information from voluntary witnesses (R. 108).

Professor Emerson then expressed his opinion concerning the factors which the district court should consider in determining the individuals' interest in refusing to testify. First, citing Milton, Jefferson, Mill, Chaffee, Holmes, Brandeis, and recent psychological studies, he testified that the "freedom of expression is essential to individual integrity and dignity" and to the right to develop and realize the individual's potentiahities (R. 108). Second, the witness said, the right of silence "recognized in the classic flag salute case" "is particularly important in modern society when so many pressures tend toward conformity" (R. 109). And, third, the individual has the right of association which "is based on the weakness of the individual as a single person to accomplish political or social change" (R. 109). Professor Emerson emphasized that society, as well as the individual, has an important interest in freedom of expression since it "is a basic and absolutely fundamental principle of the democratic process" (R. 109). He described the serious effect on the individual's interest from Congressional investigation of behefs and associations: the mere questioning of the witness inhibits him from freely expressing himself; economic harm often results such as the loss of employment; and the witness is of ten socially ostracized (R.110-111). In addition, other people besides the witness become afraid to engage in similar pohitical activity and associations (R.111). These effects are not confined, according to Professor Emerson, to the Communist Party since it is impossible to draw any clear line; the "whole area left of center . . . becomes smeared ... with the same color" (R. 111-112).

Finally, Professor Emerson stated that he thought that the forces in this country tending toward a closed society restricting independent thinking and activity were 
evidence, not only that the committee already knew what would have been petitioner's answers if he had not refused to answer, but as well that the answers sought from him were merely cumulative on the general subject of the inquiry into subversion in steel unions in the Gary area. ${ }^{138}$ So the argument was pressed that the questions and answers were unnecessary, particularly in the public session to which petitioner objected, and that the inquiry in the circumstances was for the purpose of exposure of the individual rather than in aid of legislation. This argument could be accepted without challenging the sufficiency of the authorizing resolution or the appropriateness of the general imquiry, but objecting only to the legitimacy of the particular questions addressed to this witness in the circumstances.

d. Was the questioning of petitioner concerning his membership in the Communist Party and the party's program of "colonization" of the steel industry consistent with rights protected by the first amendment? This at last is the fundamental question on which decision should be based. If the Barenblatt line of cases is to be followed, affirmance is indicated. However, the arguments against balancing away the first amendment, to this writer persuasive, suggest the desirability of reconsideration and rejection of those cases.

now stronger than those supporting an open society (R.113). In support of this judgment, he noted the great number of government employees subject to loyalty tests, the large units which dominate the economy, and the unanimity of opmion expressed by mass media and educational imstitutions (R.113-114). He therefore stated that "as of this time what is needed, in terms of freedon of expression, is that society encourage independence, unorthodoxy and differences ..." (R. 114).

Professor Emerson concluded (R.115): "My answer is, on the basis of the foregoing considerations, it is my opinion that the interests of the Government in obtaining answers to the questions put to this defendant as an aid in developing further legislation to protect internal security are substantially outweighed by the interest of the individual in freedom of speech or silence, as he may prefer, and by the interest of the community in maintaining freedom of pohtical expression and other conditions essential to maintaining an open society."

See also Emerson, Toward a General Theory of the First Amendment, 72 YaLE L.J. 877, 943-45 (1963).

${ }^{138}$ Reply Brief for Petitioner on Reargument, pp. 7-10, Yellin v. United States, No. 35 (Sup. Ct., 1962 Term). 